The Polish Journal of the Arts and Culture. New Series 12

(2/2020): 11-26 [ARTYKU‡]

DOI: $10.4467 / 24506249$ PJ.20.006.13445

\title{
Opór w czynie - na kanwie budowy Szkół - Pomników Tysiąclecia. Wydźwięk realny i medialny
}

Janusz GoŁotA

\begin{abstract}
Streszczenie
W artykule zasygnalizowane zostały różne postawy wobec akcji budowy tysiąca szkół na tysiąclecie państwa polskiego. Przedsięwzięcie miało stać się remedium na powojenną zapaść lokalową szkolnictwa i eksplozję demograficzną. Stanowiło też kampanię polityczną, której jednym z aspektów była walka z Kościołem katolickim, i tworzyło przeciwwagę dla dziewięcioletniej nowenny przed rocznicą chrztu Polski. Na przykładzie skutecznej akcji budowy tysiąclatek widoczne są różnorodne postawy: od autentycznego czy koniunkturalnego poparcia, poprzez urzędnicze wykonywanie powinności, aż po kontestację, a nawet protesty, skargi, niechęć. W praktyce zarysowała się jeszcze jedna postawa: przemilczanie, które miało dwa wymiary - w praktyce rządowej było wstrzymywaniem dyskredytujących informacji, a z drugiej strony stanowiło swoistą formę biernego oporu.
\end{abstract}

Słowa kluczowe: Kontestacja w PRL, budownictwo szkolne w PRL

Janusz GoŁota (ur. 1953), profesor nadzwyczajny w Zakładzie Historii Mediów, Wydziału Humanistycznego, Instytutu Dziennikarstwa i Komunikacji Społecznej Uniwersytetu Warmińsko-Mazurskiego w Olsztynie. Zainteresowania badawcze: historia dwudziestolecia międzywojennego w Polsce, pogranicze mazowiecko-mazurskie, relacje polsko-żydowskie, budownictwo szkolne w PRL, samorządność III RP, historia prasy. Prezes Ostrołęckiego Towarzystwa Naukowego

E-MAIL: janusz.golota@uwm.edu.pl

E-MAIL: januszno@op.pl 


\section{Wprowadzenie}

Motywem przewodnim są rozważania dotyczące kategorii oscylujących wokół oporu społecznego, takich jak: sprzeciw, bunt, niezgoda w kontekstach historycznych i społecznych. Po analizie materiału pojawiło się miejsce dla pojęcia uzupełniającego wspomniany obszar oporu: „przemilczanie”. Miało ono walor dwojaki - w praktyce rządowej było wstrzymywaniem dyskredytujących informacji, a ze strony społecznej stanowiło swoistą formę biernego oporu. Praktyczną kanwą rozważań są różne postawy wobec akcji budowy szkół Pomników Tysiąclecia Państwa Polskiego, w kontekście całego szkolnego ruchu budowlanego i uwarunkowań makroekonomicznych. Główne analizy odnoszą się do czasu istnienia Społecznego Funduszu Budowy Szkół Tysiąclecia (dalej: SFBS), od jego powstania, tj. 29 listopada 1958 roku - do 13 stycznia 1966 roku. W tym dniu doszło do połączenia SFBS z istniejącym od 1945 roku Społecznym Funduszem Odbudowy Stolicy (od 1958 Społeczny Funduszu Odbudowy Kraju i Stolicy). W wyniku scalenia powstał Społeczny Fundusz Budowy Szkół i Internatów, działający do 1972 roku. Wspomniany czasokres (1958-1966) jest najbardziej miarodajny dla zobrazowania przedmiotowych zagadnien.

Główną metodą badawczą była krytyczna analiza związanych z tematem zespołów archiwalnych ${ }^{1}$. Ponadto wykorzystane zostały materiały drukowane, dane statystyczne ${ }^{2}$ wśród nich liczne instrukcje ${ }^{3}$ oraz prasa ${ }^{4}$.

Szkolne przedsięwzięcie inwestycyjne miało stanowić remedium na powojenną zapaść lokalową szkolnictwa oraz reakcję na eksplozję demograficzną. Te kryteria są oczywiste: straty wojenne (1939-1945) w szkolnych zasobach lokalowych zostały oszacowane przez Komisję Specjalną przy Radzie

1 AAN, Krajowy Komitet Społecznego Komitetu Budowy Szkół (KSFBS) w Warszawie, syg. 1170; Krajowy Komitet Społecznego Komitetu Budowy Szkół i Internatów (KK SFBSiI), sygn. 1171; Polska Zjednoczona Partia Robotnicza, Komitet Centralny w Warszawie (PZPR, KC) nr. zespołu 1354; Biuro Ogólnopolskiego Frontu Jedności Narodu, sygn. 183, Ministerstwo Oświaty, sygn. 8413, 8415, 8334, 8444; Najwyższa Izba Kontroli, sygn. 1154

2 Roczniki Statystyczne 1958-1968; Statystyka szkolnictwa. Szkolnictwo ogólnokształcące i opieka nad dzieckiem i młodzieżą 1964/65 i 1965/66, Warszawa 1966

3 Np. Instrukcja dla Komitetów SFBS z 30 stycznia 1959 w sprawie trybu zbierania, księgowania i odprowadzania wpłat na rzecz SFBS; Wytyczne w sprawie organizowania imprez na rzecz SFBS w maju 1959. Instrukcja w sprawie rozprowadzania cegiełek SFOS i kilkadziesiąt innych.

4 Głównie: „Trybuna Ludu” i „Życie Warszawy”, „Głos Nauczycielski”, „Rada Narodowa, „Nowa Szkoła” oraz branżowy „Biuletyn Informacyjny”. 
Ministrów na 30-40\%. W wyniku trzyletniego Planu Odbudowy Gospodarczej (1947-1949) oddano do użytku tylko 9500 izb, w czasie realizacji planu sześcioletniego (1950-1955), nastawionego na przemysł ciężki i zbrojeniowy, zbudowano ich tylko $8283^{5}$. Motyw demograficzny jest również wyrazisty. Np. w 1957 roku na światp rzyszło 782300 dzieci, w 1958 - 755500 dzieci, w $1965-547400^{6}$.

Ale powołanie SFBS odzwierciedlało jeszcze jeden ważny aspekt: polityczny. Otóż budowa szkół stanowiła jeden z elementów walki władzy partyjno-państwowej z Kościołem katolickim. Punkt odniesienia stanowił rok 1966. W jego perspektywie, już 3 maja 1957 roku, prymas Stefan Wyszyński zainaugurował na Jasnej Górze Wielką Nowennę, czyli dziewięcioletnią modlitwę i pracę nad wypełnieniem Ślubów Jasnogórskich przed Jubileuszem Tysiąclecia Chrześcijaństwa Polski. W odpowiedzi, 25 lutego 1958 roku, Sejm PRL podjął uchwałę w sprawie obchodów Tysiąclecia Państwa Polskiego w latach 1960-19667. Miały być one wypełnione cyklem działań: badania naukowe, domy kultury, boiska, stadiony, muzea, szpitale, ośrodki zdrowia, pomniki, renowacja zabytków, drogi. I właśnie zbudowaniem 1000 szkół „Pomników Tysiąclecia Państwa Polskiego” - potocznie zwanych „tysiąclatkami” - postanowiono najdobitniej uczcić wielki świecki jubileusz.

W artykule w niewielkim stopniu znajdą się szczegółowe dane dotyczące liczby zbudowanych szkół, czy izb lekcyjnych (wszak izby, a nie szkoły, są jednostką statystyczną), uwypuklona zostanie przede wszystkim cała domena ideologiczna, polityczna oraz reakcje społeczne.

Formalnym mocodawcą SFBS był Front Jedności Narodu. Pracami Funduszu kierowało Prezydium Krajowego Komitetu SFBS, na czele z Marszałkiem Sejmu - Czesławem Wycechem. W ówczesnej rzeczywistości publicznej w tym w świecie medialnym - społeczny ruch budowy szkół zawłaszczyła sobie PZPR - dziękczynne adresy słano do „Towarzysza Wiesława”. Koncept wspierało wiele organizacji, w pierwszym rzędzie Związek Nauczycielstwa Polskiego i zrzeszenia spółdzielcze.

Tysiąclatki i inne szkoły „społeczne” stanowiły tylko około $35 \%$ całego szkolnego wysiłku inwestycyjnego. Generalnie, izby wznoszono ze środków pochodzących z dwóch źródeł: budżetowych i społecznych, zebranych

5 S. Zdyb, Potrzeby szkolnictwa podstawowego, Niektóre problemy budownictwa szkolnego, „Nowa Szkoła” 1960, nr 6, s. 21.

6 „Rocznik Demograficzny”, s. 28-29. Dla porównania w 2014 r. urodziło się 375 tys. dzieci.

7 Uchwała Sejmu Polskiej Rzeczypospolitej Ludowej z dnia 15 marca 1958 r. „Monitor Polski”, nr 16, poz. 98. 
głównie przez SFBS. Inwestycyjny wynik rzeczowy budownictwa szkolnego w tym okresie był znakomity. W latach 1959-1965 ogółem zbudowano 4353 szkoły podstawowe o 31700 izbach lekcyjnych, 239 szkół zawodowych o 3655 pomieszczeniach do nauki, 9 o liceów ogólnokształcących o 1329 izbach lekcyjnych, 28 szkół specjalnych o 291 izbach lekcyjnych. W powyższych wielkościach ogólnych mieściły się szkoły wzniesione ze środków SFBS w następujących wielkościach: 1105 szkół podstawowych o 9851 izbach, 54 szkoły zawodowe o 959 pomieszczeniach, 28 budynków dla liceów o 356 izbach lekcyjnych, 6 szkół specjalnych o 66 izbach. Ponadto oddano 6349 mieszkań dla nauczycieli ze środków $\mathrm{SFBS}^{8}$.

\section{Motywy oporu społecznego i państwowe sposo- by na ich przełamywanie}

Z realnego punktu widzenia opór w sprawie budowy szkół wydaje się irracjonalny. Jak można protestować, oponować w aspekcie powyższych efektów inwestycyjnych? A jednak, mimo potężnej machiny gospodarczej i propagandowej, pojawiały się różne formy sprzeciwu.

Powstaje pytanie, jakie zjawiska czy działania kontestowano? Głównym celem SFBS była zbiórka pieniędzy usankcjonowana „Instrukcją”, wyznaczającą konkretne odpisy procentowe, dotyczące teoretycznie dobrowolnych składek od wynagrodzeń czy dochodów wszystkich grup społecznych (np. 0,5\% od pracowników zakładów i instytucji, stosowne datki wyznaczono dla inny grup zawodowych $)^{9}$. Ów dokument zawierał słowa raczej obligujące do składek: „obywatele powinni”; albo - zamiast słowa powiedzmy „datek” „świadczenia”. Jednocześnie dekretował dobrowolne deklarowanie się na listach z podpisami w sprawie składek pieniężnych, czy innych form wsparcia, np. prac społecznych.

Podstawowy powód oponowania może być prosty. To kolejna zbiórka w Rzeczypospolitej żebraczej: Od 1945 składki zbierał wspomniany Społeczny Fundusz Odbudowy Stolicy, równolegle pojawiało się wiele innych podobnych akcji.

8 W. Pokora, Budujemy szkoty i internaty, „Nowa Szkoła” 1965, nr 3, s. 2.

9 Instrukcja w sprawie społecznej akcji budowy 1000 szkót dla uczczenia Tysiąclecia Państwa Polskiego (dalej Instrukcja), grudzień 1958. 
Entuzjazmu zbiórkowego jednak nie było, a raczej wystąpiła nieprzychylność. Sprowokowała ona presję całej machiny polityczno-urzędniczej, mającą na celu przełamanie dezaprobaty, co świadczy o znaczącej fali niechęci. Najwyższe władze polityczne nawiązywały do tysiąclatek, począwszy od zjazdów PZPR, poprzez zgromadzenia innych podmiotów życia publicznego, konferencje, manifestacje, uroczystości, monity, sprawozdania, nakazy, urzędnicze wezwania ${ }^{10}$. Dzielnie wtórowała prasa ${ }^{11}$.

$\mathrm{W}$ różnych środkach ówczesnego przekazu: urzędniczych, w tym ministerialnych, pism najwyższego szczebla, wychodziło co miesiąc od kilku do kilkunastu odezw, nakazów, próśb - dotyczy to zwłaszcza 1959 roku. Mobilizowały one do zbiórek, upraszczały procedury ich realizowania. Formą nacisku były sprawozdania terenowych jednostek organizacyjnych SFBS: miesięczne, kwartalne, roczne, oraz kontrole prowadzone przez te organy. Słowo „datek”, zastąpiono dyspozycją „obowiązek”.

Podczas narad po kontroli NIK proponowano różne metody prowadzące do większej „ściągalności świadczeń”, napiętnowano opieszałych na zebraniach gminnych ${ }^{12}$. Komitety SFBS, sołtysi, przedstawiciele prezydiów rad narodowych wzajemnie obarczali się odpowiedzialnością za niedostatki ${ }^{13}$.

${ }^{10}$ Pismo ministra finansów z 3 lutego 1959 r., AAN, 1170, t. 1, k. 5; List przewodniczącego KK SFOS Czesława Wycecha do przewodniczących prezydiów rad narodowych z 8 lutego 1960 r., tamże, t. 3, k. 10-11; Informacja o budowie szkół Tysiąclecia, PZPR, 237/XVI - 301, k.3 4; List Ministra do nauczycieli w sprawie udziału szkół i innych placówek oświatowowychowawczych w obchodach Tysiąclecia Państwa Polskiego, Dz. U. MO, nr 3, 10 III 1960, poz. 30 .

${ }^{11}$ Np.: Grosz do grosza i będzie szkoła, „Głos Nauczycielski”, nr 16, 17 IV 1960; [w. m.] Budujemy szkoty Tysiaclecia, tamże, $\mathrm{nr} 21,22 \mathrm{~V}$ 1960; [W. M.] Najpilniejsze zadania i terminowe wykonawstwo, tamże, nr 27-28, 10 VII 1960; L. Stasiewicz, Piękny przykład opolskiej młodzie$\dot{z} y$, tamże, nr 3, 17 I 1960; W. Michalski, O większa ofiarność społeczeństwa na budowę szkót Tysiąclecia, tamże, nr 2, 10 I 1960.

${ }^{12}$ Pismo Delegatury NIK do Kuratora Okręgu Szkolnego a do wiadomości do Prezesa NIK, I sekretarza KW w Olsztynie, sekretarza propagandy KW w Olsztynie, Sekretarz KW w Olsztynie, Prezydium WRN w Olsztynie, Komisji Oświaty Kultury WRN w Olsztynie, Prokuratora Wojewódzkiego w Olsztynie, WK FJN, oraz dwóch wewnętrznych komórek: Zespół Nauki i Kultury NIK, Zespół Budownictwa NIK, Archiwum Państwowe w Olsztynie, sygn. 489 , t. 101, k. 71.

${ }^{13}$ Protokół z narady z przewodniczącymi GRN w sprawie uwag i wniosków po przeprowadzonej kontroli w Powiatowych i Gromadzkich Radach Narodowych w dniu 29 lipca 1965 roku w Pasłęku, tamże, k. 101. 


\section{Cegiełki: oficjalne protesty}

Najbardziej kontrowersyjnym był proceder finansowania tysiąclatek poprzez cegiełki. W 1959 roku Państwowa Wytwórnia Papierów Wartościowych wykonała bloczki cegiełek dla SFBS ${ }^{14}$ o wartości nominalnej 2365 mln zł. Akcja rozprowadzania przynosiła mierne rezultaty ${ }^{15}$. „Do Komitetów SFBS, prasy i radia zaczęły napływać listy domagające się uchylenia decyzji. Wskazywano na zbędne koszty związane z produkcją. Niektóre zakłady pracy podejmowały decyzje, że załogi nie będą przyjmować cegiełek, podobnie komitety koordynacyjne (w woj. opolskim) domagały się zaniechania akcji” ${ }^{16}$. Krytycznie, a nawet $\mathrm{z}$ niechęcią, do cegiełek odnosiły się nawet komitety partyjne ${ }^{17}$. Kolportażowi przeciwstawiały się komórki finansowe zakładów pracy i instytucji, obarczone dodatkowymi obowiązkami biurokratycznymi. Krytyczne uwagi pojawiły się w prasie, za przykład niech posłuży felieton w „Słowie Polskim”: „Może jeszcze nie jest za późno, może światli ludzie kierujący zbiórką na Społeczny Fundusz Budowy Szkół potrafią przekonać kogo trzeba, że akcja rozprowadzania cegiełek jest najzupełniej niepotrzebna, pochłania czas i energię a równocześnie sporo kosztuje”, Autor postawił rzeczowe pytanie: „A komu te cegiełki są potrzebne?”. „Gdyby ta rezygnacja dała w efekcie choć jedną izbę lekcyjną - to warto się o nią pokusić ${ }^{18}$. I jeszcze jedna sprawa. Panowała opinia, że składki wzrastają w miejscowościach, gdzie budowana jest szkoła. Ale jest też przykład odmienny, np. w Olsztynku, rodzice na budowę szkoły dla swoich dzieci wpłacili tylko kilkaset złotych ${ }^{19}$.

W podsumowaniu treści dotyczących zbiórek pojawia się retoryczne pytanie. Na ile dezaprobata była reakcją na wszechobecność PZPR w akcji zbiórkowej, zwłaszcza podczas uroczystości otwarcia, czy nadawania imion szkołom. Pieniądze składkowe, a na trybunach sekretarze, adresy do „Wiesława”. Niechęć mogło wzbudzać nadawania imion szkołom. Np. Poległych Bohaterów Milicji Obywatelskiej i Służby Bezpieczeństwa (Łądzyń pow. Mińsk Mazowiecki), XX-lecia PRL, Armii Czerwonej. Szkole w Łądzyniu patronuje teraz Krzysztof Kamil Baczyński. W jej historii zamieszczonej w Internecie wspomniana jest jako tysiąclatka, ale pierwszy patron został pominięty.

\footnotetext{
${ }^{14}$ Pismo PWPW do OK FJN z 18 VII 1959, AAN, t. 2, k. 19.

${ }^{15}$ Zestawienia - notatki służbowe, AAN, 1171, t. 30, k. 118, 120, 124-5, 127-136

${ }^{16}$ Notatka w sprawie cegiełek SFBS, AAN PZPR, 237/XVI - 516, k. 9-11

${ }^{17}$ Notatka z maja 1960 roku, tamże 237/XVI - 301, k. 16.

${ }^{18}$ R. Skała, Komu cegietke, „Słowo Polskie”, nr 43, 20 II 1960.

${ }^{19} \mathrm{~W}$. Michalski, O większa ofiarność społeczeństwa...
} 
Oczywiście patronami częściej byli też uznani powszechnie bohaterowie narodowi, pisarze, uczeni.

\section{Zwyczajna polemika}

Warta odnotowania jest polemika Mikołaja Kozakiewicza z kwietnia 1960 roku. We współczesnym nam realiach byłby to normalny głos $\mathrm{w}$ dyskusji, $\mathrm{w}$ tamtych czasach stanowił swoisty ewenement. Autor zastanawiał się, „czy te zgromadzone miliardy należy rzeczywiście przeznaczać na masywne, murowane szkoły w małych miejscowościach i osiedlach, właśnie dla szkół podstawowych”. Argumentował, że gdy szkoły podstawowe zostaną zbudowane, to wyż wkroczy już do szkół średnich, a populacja uczniów podstawowych zmniejszy się. Ponadto przekonywał do baraków, przystosowanych do demontażu i przemieszczania - przywołując - o zgrozo - nie Związek Radziecki, ale Wielką Brytanię, Francję, Niemicy Zachodnie i Belgię. „Nie mam żadnej sympatii dla kapitalistów. Ale w jedno u nich wierzę: w trzeźwość kalkulacji i umiejętność określania tego co się opłaca. Czy nie warto by i u nas przemyśleć taką kalkulację?”20. Artykuł wywołał dyskusję, trzy głosy reprezentatywne zamieścił „Głos Nauczycielski”. Od przyjęcia artykułu przez polemistów jako żart primaaprilisowy, poprzez rzeczową akceptację, przytaczającą przykłady nietrafionych gigantów w małych miejscowościach albo pochwałę eksperymentowania celem pomniejszenia kosztów budowy ${ }^{21}$. Po pięciu latach Kozakiewicz ideę tysiąclatek uznał za „najoryginalniejszy i najpiękniejszy sposób uczczenia rocznicy historycznej”22.

\section{$5 \quad$ Skargi}

Lekceważenie dobrowolności powodowało wiele skarg. W pierwszym kwartale 1961 roku do Polskiego Radia wpłynęło 120 protestów przeciwko wymuszaniu świadczeń. Jedna z nauczycielek z powiatu kępińskiego napisała list do Polskiego Radia, w którym użalała się na rolę inkasenta w stosunku do chłopów ${ }^{23}$. Podobne skargi wpływały do „Przyjaciółki”, „Chłopskiej Drogi”, pojawiały się użalania na sołtysów.

\footnotetext{
${ }^{20}$ M. Kozakiewicz, Kilka herezji w sprawie budowy szkót, „Głos Nauczycielski”, nr 14, 3 IV 1960.

${ }^{21}$ Trzy głosy w sprawie szkół Tysiąclecia, „Głos Nauczycielski”, nr 16, 17 IV 1960.

${ }^{22}$ M. Kozakiewicz, 1000 szkót i co dalej, „Głos Nauczycielski”, nr 35, 29 VIII 1965.

${ }^{23}$ Stenogram przebiegu posiedzenia KK SFBS z dnia 22 VI 1961, AAN, t. 20, k. 48.
} 


\section{Niedowład organizacyjny (niechęć?) i remedium rządu}

Budowa struktur terenowych przebiegała opieszale, dlatego, za sprawą FJN, organizacją pracy zostały obarczone rady narodowe. Podjęto nawet inicjatywę, żeby przewodniczącymi wojewódzkich komitetów koordynacyjnych SFBS zostawali wiceprzewodniczący wojewódzkich $\mathrm{rad}$ narodowych ${ }^{24}$, na których nałożono obowiązek organizowania struktur SFBS, zbierania ogromnej ilości sprawozdań, instrukcji, upomnieńn ${ }^{25}$.

Praktyka pokazała, że niemożliwe jest skuteczne działanie bez pracowników etatowych w terenie. Dlatego 15 maja 1959 minister oświaty podjął następującą decyzję: „Ze względu na doniosłe znaczenie Komitetu Społecznego Funduszu Budowy Szkół [...] pozwalam na oddelegowanie jednego nauczyciela lub innego pracownika oświatowego zatrudnionego w placówce podległej Inspektorowi Oświaty do pracy w każdym powiatowym komitecie SFBS”. Minister oczekiwał, iż będą to nauczyciele cieszący się autorytetem w środowisku, wyróżniający się aktywnością i doświadczeniem organizacyjnym $^{26}$. Na szczeblu wojewódzkim sprawami SFBS zajmowało się dwóch - trzech pracowników, usytuowanych najczęściej w biurach kuratorium oświaty.

Efektywność terenowych komórek SFBS (43614 komitetów skupiających w swych szeregach 180 tys. działaczy ${ }^{27}$ ) była zróżnicowana, co potwierdziła kontrola przeprowadzona w 1965 roku przez $\mathrm{NIK}^{28}$. Niekiedy formalnie powołane komitety nie przejawiały żadnej aktywności. W znacznej liczbie prezydia rad narodowych nie zabezpieczyły obsługi w zakresie spraw finansowych, technicznych i administracyjno-biurowych, wskutek czego czynności te wykonywali oddelegowani przez inspektoraty oświaty nauczyciele. $\mathrm{Na}$ marginesie, kontrola NIK, kierowanej przez swoistego dysydenta, Romana

\footnotetext{
${ }^{24}$ Pismo OK FJN z 13 lutego 1959 roku do biur wojewódzkich FJN, podpisane przez sekretarz biura Zofię Tomczyk, tamże, s. 37.

${ }^{25}$ List Sekretarza KKSFBST. Wysockiego do Wojewódzkich Komitetów SFOS z 18 marca 1960 roku. AAN, 1170, t. 3, k. 23.

${ }^{26}$ Okólnik Ministra Oświaty z 15 maja 1959 roku, AAN, 1170, t. 2, s. 9; Pismo Ministerstwa Oświaty do kuratorów okręgów szkolnych i wojewódzkich komitetów koordynacyjnych SFBS z 30 maja 1959, tamże, s. 138.

${ }^{27}$ Sprawozdanie wygłoszone podczas plenarnego posiedzenia Komitetu Krajowego SFBS w dniu 13 I 1966, AAN, t. 24, k. 9 dokumentu.

${ }^{28}$ Sprawozdanie Poufne NIK, AAN, sygn. 1154, t. 29/4.
} 
Zambrowskiego ${ }^{29}$, była bardzo rzeczowa i krytyczna, wskazywała na mankamenty, niedoróbki, nadużycia, bez słów o socjalizmie, wartościach etc. Oczywiście, wiele komitetów SFBS działało prężnie i z autentyczną wiarą w misję budowy szkół. Ale bez interwencji państwa ruch SFBS by nie zafunkcjonował.

\section{$7 \quad$ W praktyce inwestycyjnej}

Zapewne kierownictwa SFBS nie radowały reakcje przedsiębiorców, którzy niechętnie przyjmowali zlecenia, będące pod publiczną obserwacją, obarczone szczególnymi oczekiwaniami, kontrolami „społecznych inspekcji pracy”, nalotami prasowymi etc. O niechęci świadczą liczne próby wywierania presji na wypełnienie portfela zamówień inwestycjami szkolnymi ${ }^{30}$.

Ambiwalentnie przyjmowano czyny społeczne wokół szkół wznoszonych różnym sumptem. $Z$ jednej strony był to ideologiczny, immamentny element gospodarki socjalistycznej, z drugiej zaś - uciążliwość dla czynodawców i czynobiorców - jeśli można użyć takich neologizmów. Szczególna niechęć pojawiała się wśród firm budowlanych ${ }^{31}$, które po prostu traciły zyski, wynikające np. z transportu materiałów budowlanych, czy marżę nakładaną na materiały budowlane ${ }^{32}$. $\mathrm{Z}$ dystansem do czynów podchodziły władze SFBS. „Czyny społeczne w wielu wypadkach nie spełniają swojej roli i w konsekwencji przedłużają okres budowy i nie przyczyniają się do potanienia kosztów"33. Prace społeczne zalecono tylko przy uporządkowaniu otoczenia po zakoń-

${ }^{29}$ A. Sowa, Historia polityczna Polski 1944-1991, s. 296. R. Zambrowski podczas XV plenum $\mathrm{KC}$, w marcu 1964 roku, krytykował system gospodarczy nastawiony na przemysł kosztem infrastruktury i budownictwa, oraz funkcjonowanie administracji państwowej i instancji partyjnych

${ }^{30}$ Protokół nr 1 z posiedzenia Prezydium KK SFBS w dniu 8 stycznia 1959, AAN, t. 18, k. 64; 45 tysięcy izb lekcyjnych główny problem szkolnictwa podstawowego, „Trybuna Ludu”, $\mathrm{nr}$ 154, 6 VI 1960, wyd. C.

${ }^{31}$ Wypowiedź T. Araszkiewicza. Protokół z posiedzenia Prezydium SFBS z dnia 25 V 1961 , AAN, 1961, t. 20, k. 14 .

${ }^{32}$ Wypowiedź posła K. Zachajkiewicza na posiedzeniu sejmowej Komisji Oświaty i nauki 9 listopada, Sprawy gospodarcze w Sejmie. Budownictwo szkót, „Życie Gospodarcze” nr 47, 25 XI 1962, s. 2.

33 Wypowiedź dyrektora Rasińskiego z Ministerstwa Budownictwa i dyrektora Pająka z Katowic, Protokół z posiedzenia Prezydium SFBS z dnia 25 V 1961, AAN, t. 20, k. 19. 
czeniu budowy ${ }^{34}$, wskazując, aby były to „siły fachowe”35. Oczywiście można podać też wiele przykładów użyteczności czynów społecznych, zwłaszcza w wykończeniach, „bez drastycznych oszczędności i nadmiernych kosztów”.

\section{Przemilczenia}

W 1961 roku zmieniła się strategia medialnego podejścia do zbiórek: „Ponieważ procentowe wyniki zbiórki w poszczególnych grupach, które nie wykonują planów, nie są oceną społeczeństwa, a złej organizacji pracy - nie podawać krytycznym ocenom w prasie radio i telewizji" ${ }^{6}$. Dla Prezydium KK SFBS zastrzeżono prawo do publikowania wiadomości o ponadplanowej liczbie wznoszonych szkół oraz o trudnościach wynikających z braku limitów inwestycyjnych, w obawie o osłabienie woli dalszego społecznego dotowania.

Wobec całej propagandy siedmiolecia zagadkowo wyglądało oddanie tysięcznej tysiąclatki - 18-izbowej szkoły podstawowej na Woli w Warszawie, przy ulicy Ożarowskiej, której nadano imię Hugo Kołłątaja. Wydział Nauki i Oświaty KCPZPR zaproponował połączenie podniosłej uroczystości z wiecem, z udziałem młodzieży, społeczeństwa, delegacji zakładów pracy, dostojników, na którym KK SFBS ogłosiłby zakończenie akcji konstatacją: „rzucone przez tow. Gomułkę hasło zostało zrealizowane"37. Ale, co ciekawe, Gomułka, „wielki budowniczy tysiąclatek”, na uroczystość nie przybył, mimo udziału wielu najwyższych dostojników państwowych ${ }^{38}$. A wcześniej Biuro Polityczne zajęło się ustaleniem np. „Programu Dni Morza”, przyjęciem daty dożynek, ale nie znalazło czasu na omówienie oddania tysiąclatki ${ }^{39}$.

${ }^{34}$ Z obrad Prezydium KK SFBS, Sekretariat Ogólnopolskiego Komitetu Frontu fedności Narodu „Biuletyn Informacyjny”, nr 7, 1 VI 1961, s. 14-17; Protokół z posiedzenia Prezydium SFBS z dnia 25 V 1961, AAN, 1961, t. 20, k. 22.

35 Tamże, k. 19.

${ }^{36}$ Protokół z posiedzenia Prezydium SFBS z dnia 17 I 1961, tamże, k. 4.

37 Uchwała plenum KK SFBS z 20 stycznia 1965 roku, „Biuletyn Informacyjny” nr 2, 15 II 1965, s. 9; Notatka z dnia 27 lipca 1965 roku w sprawie uroczystości oddania do użytku tysięcznej szkoły, AAN, KC PZPR, t. 516, k. 47-48.

${ }^{38} \mathrm{~W}$ uroczystości otwarcia tysięcznej tysiąclatki uczestniczyli m.in. Marszałek Sejmu i przewodniczący Ogólnopolskiego Komitetu SFBS Czesław Wycech, sekretarz KC PZPR Witold Jarosiński (minister oświaty 1950-1956); Wacław Tułodziecki; minister budownictwa i materiałów budowlanych Marian Olewiński; I sekretarz KW Stanisław Kociołek; przewodniczący WRN Józef Pińkowski; Naczelnik ZHP Wiktor Kinecki. Tysięczna Tysiąclatka otwarta $w$ Warszawie, Korespondencja PAP, „Trybuna Ludu”, nr 246, 6 IX 1965, wyd. C.

${ }^{39}$ Protokół nr 19 z posiedzenia Biura Politycznego 7 IX 1965, AAN mkf, 2895, k. 67. 
Podobnie z prasą. Pierwsza strona „Trybuny Ludu” została zdominowana przez Centralne Dożynki, dopiero lewa dolna część informuje „Tysięczna Tysiąclatka otwarta w Warszawie”. „Życie Warszawy” obie informacje umieściło na pierwszej stronie, zdjęcie Gomułki przy tekście dotyczącym doży$n^{44^{0}}$. Ponadto „Życie” wydało bogaty w fotografie dodatek nadzwyczajny, prezentujący bryłę budynku, wyposażenie pracowni, społeczność szkoły ${ }^{41}$. Inne dzienniki, np.: „Nowiny”, „Gazeta Robotnicza”, zamieściły skromny komunikat PAP, marginalnie wyglądający na tle informacji o dożynkach, czy Dniu Energetyka.

W powyższym kontekście retorycznie można by zapytać - czyżby opór przeciw własnemu dziełu? Wyciszanie szumu medialnego po czasie prosto wyjaśnił Czesław Wycech „by nie spowodować spadku wpływów z racji wypełnienia programu" ${ }^{2}$.

\section{Kościół a tysiąclatki}

Opisywany czas to nasilenie walki z Kościołem katolickim, również w szkołach. Ukoronowaniem batalii była ustawa z 1961 roku: „Szkoły i placówki oświatowo-wychowawcze wychowują w duchu socjalistycznej moralności i socjalistycznych zasad współżycia społecznego w duchu umiłowania Ojczyzny, pokoju wolności, sprawiedliwości społecznej i braterstwa z ludźmi wszystkich krajów, uczą zamiłowania i szacunku do pracy, poszanowania mienia narodowego, przygotowują do czynnego udziału w rozwoju kraju, jego gospodarki i kultury [...] Całokształt nauczania i wychowania w tych instytucjach ma charakter świecki"43. Socjalistyczny i świecki charakter szkoły zaskutkował ostatecznie likwidacją nauki religii w szkołach ${ }^{44}$ i przeniesieniem jej do punktów katechetycznych oraz zdejmowaniem krzyży, czyli „dekrucyfikacją”. Gomułka, bez uwzględnienia powyższych uwarunkowań, zarzucał Kościołowi bierność: „Obchodzimy 1000-lecie państwa polskiego wielkim dorobkiem władzy ludowej... darem w postaci zbudowania ponad 1000

40 „Życie Warszawy”, nr 213, 5-6 IX 1965.

$4^{11}$ „Życie Warszawy”, dodatek ilustrowany do dzienników, nr 351, 5 IX 1965.

${ }^{42}$ Wystąpienie Czesława Wycecha $\mathrm{w}$ dyskusji podczas plenarnego posiedzenia KK SFBS w dniu 20 stycznia 1965, AAN, t. 24, k. 71 dokumentu.

43 Ustawa z dnia 15 lipca 1961 roku o rozwoju systemu oświaty i wychowania, Dz. Ustaw 1961, nr 32, poz. 160; Sejm uchwalit reformę szkolnictwa. Zamknięcie wiosennej sesji parlamentu, „Trybuna Ludu” nr 194, 17 VII 1961.

${ }^{44}$ Ustawa z dnia 15 lipca $1961 \ldots$, tamże. 
szkół. Do tej akcji kościół się nie przyłączył - zajmował całkowicie bierne stanowisko. Gdyby czuł patriotyczny obowiązek, gdyby był związany z ustrojem, to by ten czyn poparł, kościół jednak tego nie uczynił" 45 . W tym kontekście najbardziej wyrazistym jednostkowym przejawem buntu były wydarzenia z 27 kwietnia 1960 roku $^{46}$ w Nowej Hucie, w której Gomułka widział wzorcowe socjalistyczne miasto bez świątyń. Po zabiegach władz kościelnych wydano wstępne zezwolenie na budowę świątyni, a wierni ustawili krzyż na placu budowy. Niebawem, zasłaniając się potrzebą budowy szkoły, wycofano wcześniejszą zgodę, co doprowadziło do impulsywnych rozruchów. Nie był to oczywiście bunt mieszkańców przeciwko szkole ale obrona krzyża, w walce z oddziałami ZOMO i milicji. Krzyż obroniono, ale władze nie zrezygnowały z budowy tysiąclatki, którą wzniesiono jako Szkołę Podstawową $\mathrm{nr} 87 \mathrm{im}$. Janka Krasickiego. W AAN zachowało się przemówienie, które podczas uroczystego otwarcia 16 września (w dokumentach ministerialnych 10 września) 1961 roku wygłosił Leon Kruczkowski ${ }^{47}$, ówczesny członek Rady Państwa. Mówca sławił osiągnięcia PRL, np. „siedmiokrotne zwiększenie produkcji, dzięki przemysłowi, którego właścicielem jest naród wspierany braterską pomocą narodu i rządu radzieckiego”. Wskazał na fundatora „czyli czołowy oddział polskiej klasy robotniczej - przez załogę Nowej Huty - dla jej dzieci, dla młodzieży tego socjalistycznego miasta”. Zdarzenia dotyczące ustawy z 1961 roku oraz powyższy przykład może naprowadzić do wniosku, że oczekiwanie pomocy Kościoła było po prostu cynizmem.

\section{Podsumowanie}

Pierwszy wniosek uniwersalny. Postawy wobec tysiąclatek były zróżnicowane, od entuzjastycznego poparcia, do dystansu czy kontestacji, a nawet czynnego czy biernego oporu. Sytuacja wokół budowy tych szkół jest symptomatycznym kadrem dokumentującym życie społeczne, cele polityczne oraz kondycję gospodarczą w PRL: upolitycznione planowanie gospodarcze, ideologizowanie życia społecznego - a zwłaszcza szkoły, nadmierna materia-

\footnotetext{
45 Przemówienie Gomułki wygłoszone na plenum OP FJN 14 stycznia 1966 r., „Trybuna Ludu”, nr 15, 16 I 1965, wyd. C, s. 3; Z obrad Sesji OK FJN, „Głos Nauczycielski”, nr 4, 23 I 1966.

${ }^{46}$ J. Eisler, Zarys dziejów politycznych Polski 1944-1989, Warszawa 1989, s. 79; A. L. Sowa, Historia polityczna Polski 1944-1991, s. 315; R. Terlecki, Polska w niewoli 1945-1989. Historia sowieckiej kolonii, Kraków 2015, s. 249.

${ }^{47}$ Leon Kruczkowski na otwarcie szkoły w Nowej Hucie, IX 1961, AAN, t. 16, k. 24-31.
} 
łochłonność inwestycyjna, siermiężne wykonanie, różne formy nacisku machiny państwowej. Ale, co ważne, mimo zróżnicowanego podejścia szkoły powstały, co zapobiegło katastrofie lokalowej. Był to bardzo korzystny czas dla inwestycji szkolnych w czasie „II etapu industrializacji”. Protestowano przeciwko nadużyciom, wymuszeniom, deformacjom. Oczywiście, mankamentów w realizacji można wymieniać wiele. Ale trzeba stwierdzić, że sam proces budowy szkół, w odniesieniu do ówczesnych czasów, zakończył się sukcesem. Natomiast kwintesencję wszelkich działań związanych z edukacją w PRL, między gorliwością, konformizmem a kontestacją, stanowi liczba 10 mln członków Solidarności. Zjawisko jest między innym efektem różnego rodzaju dezaprobaty, która istniała w różnym stopniu natężenia, mimo pozornego poparcia i uczestnictwa w czynie kierowanym przez władze PRL, również w dziedzinie budownictwa szkolnego. 


\section{Bibliografia}

\section{Źródła archiwalne}

1. Archiwum Akt Nowych.

(a) Krajowy Komitet Społecznego Funduszu Budowy Szkół w Warszawie, sygn. 1170.

i. Posiedzenia KK i Komisji, t. 18 (1959), t. 16 (1961), t. 24 (1966).

ii. Zarządzenia i Wytyczne, t. 2 (1959), t. 3 (1960).

(b) Krajowy Komitet Społecznego Funduszu Budowy Szkół i Internatów w Warszawie sygn. 1171, t. 30.

(c) Najwyższa Izba Kontroli, sygn. 1154, Kontrola działalności społecznego Komitetu Funduszu Budowy Szkół - opracowanie zbiorcze, st. inspektor St. Skoroszewski, data rozpoczęcia 1 III 1965 data zakończenia: 30 IX 1965. Sprawozdanie Poufne NIK, AAN, sygn. 1154 , t. $29 / 4$.

(d) Polska Zjednoczona Partia Robotnicza, Komitet Centralny, Wydział Nauki i Oświaty, sygn. 1354.

i. Dział Oświaty, 1960-1962, 237/XVI - 301.

ii. Społeczny Fundusz Budowy Szkół, 1965-1966,237/XVI - 516.

(e) Biuro Polityczne, mkf, 2895.

2. Archiwum Państwowe Olsztyn, Wojewódzki Komitet Frontu Jedności Narodu, sygn. 489 , t. 97, 101.

\section{Źródła drukowane}

Co każdy obywatel o budowie szkót tysiąclecia w $w$ Łodzi wiedzieć powinien, wyd. Łódzki Komitet Społecznego Funduszu Budowy Szkół, Łódź, listopad 1960.

Instrukcja w sprawie społecznej akcji budowy 1000 szkót dla uczczenia Tysiąclecia Państwa Polskiego, Ogólnopolski Komitet Frontu Jedności Narodu i Krajowy Komitet Społecznego Funduszu Budowy Szkół Warszawa, grudzień 1958 roku, bez daty dziennej.

Statystyka urodzeń i zgonów po II wojnie światowej, „Rocznik Demograficzny”, Główny Urząd Statystyczny, 2012, s. 28-29. 


\section{Opracowania}

Architektura i budownictwo szkolne PRL, red. J. Dobek, Z. Huszcza, F. Krysiak, J. Łoziński, Cz, Szymanek, Z. Szymański, A. Uniejewski, T. Wysocki, Wydawnictwa Szkolne i Pedagogiczne, Warszawa 1976.

Dudek A., Gryz R., Komuniści i Kościót w Polsce (1945-1999), Społeczny Instytut Wydawniczy Znak, Kraków 2006.

Dudek A., Zblewski Z., Utopia nad Wista: historia Peerelu, Wydawnictwo Szkolne PWN, Warszawa, Bielsko-Biała, 2008.

Eisler J., Zarys dziejów politycznych Polski 1944-1989, BGW, Warszawa 1992. Friszke A., Opozycja polityczna w PRL 1945-1980, A. Wyd. Aneks, Londyn 1994.

Gołota J., Społeczny Fundusz Budowy Szkót, Powstanie, przykłady działalności, efekty (1958-1966), [w:] Polska Ludowa 1944-1989 - wybrane problemy historii politycznej i społecznej, red. D. Litwin-Lewandowska, K. Bałękowski, Wydawnictwo Tygiel, Lubin 2016, s. 302-316.

Gołota J., Around the social construction of schools in the Olsztyn voivodeship 1959-1965: (politics, economy, social communication), [w:] Past and contemporary contexts of school education in Warmia and Mazury. Pt. 1, Selected problems of the school education system in Warmia and Mazury: from II Republic of Poland to the end of the eth century, Wydawnictwo Uniwersytetu Warmińsko-Mazurskiego, Olsztyn 2018, s. $83-103$.

Krzysztofowicz-Kozakowska S., Krasny, P., Walczak M., Sztuka w czasach PRL, Wydawnictwo Kluszczyński, Kraków 2007.

Paczkowski A., Strajki, bunty, manifestacje jako „polska droga” przez socjalizm, Poznańskie Towarzystwo Przyjaciół Nauk. Poznań 2003.

Rozłuski J., Rozwój oświaty na wsi w latach 1945-1973: studium o inicjatywie społecznej, Państwowe Wydawnictwo Rolnicze i Leśne, Warszawa 1974.

Sowa A. L., Historia polityczna Polski 1944-1991, Wydawnictwo Literackie, Kraków 2011.

Terlecki R., Polska w niewoli 1945-1989. Historia sowieckiej kolonii, Wydawnictwo AA, Kraków 2015.

\section{Prasa}

„Biuletyn Informacyjny”, „Głos Nauczycielski”, „Nowa Szkoła”, „Słowo Polskie”, „Trybuna Ludu”, „Życie Gospodarcze”, „Życie Warszawy”. 


\title{
Abstract, keywords, about the author
}

\begin{abstract}
Resistance in the act - on the canvas of the construction of Schools - Monuments of the Millennium

The article indicates various attitudes towards the construction of a thousand schools to celebrate the millennium of the Polish state. The undertaking was to provide a remedy for the post-war collapse of housing, a demographic explosion. It was also a political campaign, one of the aspects of which was the fight against the Catholic Church, including the 9-years Novena before the anniversary of the baptism of Poland. On the example of an effective campaign to build schools, various attitudes are visible: from authentic or opportunistic support, through official performance of duties, to contestation and even protests, complaints, and reluctance. In practice, one more attitude emerged: silence, which had a twofold value - in government practice it was withholding discrediting information, and on the other hand it was a kind of passive resistance.
\end{abstract}

Keywords: Contestation in the PRL, school construction in the PRL

Janusz GoŁOTA (1953), professor at the Institute of Journalism and Communication at the Faculty of Humanities at the University of Warmia and Mazury in Olsztyn. Research fields: interwar period 1918-1939, Mazovian region and its borders, Polish-Jewish relations, educational infrastructure in PRL, local government after 1989. President of the Ostrołęka Scientific Society.

E-MAIL: janusz.golota@uwm.edu.pl

E-MAIL: januszno@op.pl 